LEILA SUJIR, a Calgary writer and filmmaker, was born in India and has lived in Canada since 1956. She is currently teaching in the English Department at Mount Royal College. "The Movement of She and Sand" is part of a series; another section, "There is a She Who Keeps Moving in the Story," has been published in the Fall 1986 issue of The Dinosaur Review.

\title{
The Movement of She and Sand
}

LEILA SUJIR

au bord de la mort et de la vie

the land moving now

underneath feet walking

the sand and she

writing

a customs agent - she translates

events: at the border (the beach, the edge) between life and death on the sea between living on (writing) and death (of the author)

Or: at the borderline (the edge) between the death (of the author) and the birth (of the reader)

she reads events, faces

signs tell her story

she notes the feminine

(life, death and language [la langue: "tongue;

language; step of land... "])

from writing on stones - her past, forgotten

to talking on sand - land, she and sand see

Scheherazade moving along the beach

the king, now old, beside her still

listening

She is an agent of change in a male kingdom. Re-telling the male story, she tells the male (King) a story. She, not a Queen, but the agent between the old and the new - life and death, her stories.

sea breezes

air between them full of breaths each taking her closer to death 
the body's talking telling

moves her, Scheherazade, along the border, the beach of the

sea

between life and death

Those who can't tell their stories face death in Scheherazade's world of the Arabian Nights. She knew this and re-read the stories searching for a clue. Knowing she was to be one of the young virgins to be picked by the King. and seeing the death that was ahead of her, Scheherazade decided to change the story line. Determined not to be executed, she formed a plot. For Scheherazade, narrating equals living.

She paused - a breath in her story .... a life.

The stories she told began to put together a world: her life in fragments, her sense of non sense. He laughs. Then she told him the grammar of plot - then and then and then collapses his world.

Scheherazade knew that the fiction made her real. Telling pushed time on. Moved her further along the beach. The moving sand and she - earth moving under her feet. Shakes her static image, his gaze shattered glass crashing. Earth quakes.

Now she the subject $\mathrm{i}$ - these two - she and i talking to you construct our selves. His gaze unmade: now the domestic scene dissolves. The Land and she move underneath him, out from under. Her stories unmake béds, unwash dishes, undo laundry, uncook meals, unravel his story. His layers of skin wear torn surfaces. Something else emerges now from the cracks.

Her making up the story - not a romance where the he and she are making-up (a coming together) but quest - her version of her other self, an other's story.

Both her sister and she - agents in the male world of power and authority, banking and business, credit and debit. His insurance against change, against death, against love and loss and other. And her sister said, "If we can get one man to the moon, why can't we get them all there?" The King, alarmed, this mention of moon, another land - form of the feminine tides, sea pulling up towards - and these women. Darkness to his sun? Now thrown into another story, he sees himself: quaking displaced authority. He has to eat his words: a change of taste. He has to read the story she is telling.

She begins with the journey up to the mouth of the river, mapping the geography of her body. "The horror, the horror," she exclaims at his claims upon her as land, property. Undoes his map of her as place, a fixed point that he, the wandering hero, returns to. Scheherazade is moving too, her journey now in story. She is out of the house and on the beach at the edge/ the border of life and death: her quest for self. Somewhat a stranger, even to 
herself, she begins to give back the memory he housed in her: his voice located in her body contains details of a life, days, lists, desires not her own.

She begins again: a dream from her body of speech, speaking in tongues without forks. Tells him it takes lips to talk and mouth and tongue. Cave of the sea. Oracled speech. Reclaiming her body's language. Roaring, spits out the words which wind around, wound and tangle her up: her body no longer the ground of his emotions. Her body no longer place or house or garden. She tells him of cunctipotence. She displaces the all knowing father. Re-turns the word. Tells him:

the cunt is not a mail box where you deliver the pain

the cunt is not a garden of Eden - the beginnings of

paradise, the fall and Adam and Eve - what she got stuck

with - her body location evil

the cunt is not a gymnasium

the cunt is not an exit from the world, a temporary escape into pleasure and pain

The geography of her body previously his territory. The object of his gaze unfixed by the points she was making: the cunt is not a place for the King to journey from and to, making his claim upon her (landrights), but like she and the sand, it too is moving. Is telling story, speaking from another mouth, lips and tongue. The body's garden caved oracled coved. It is the tongue, the speaking which terrifies the King.

She re-tells the male stories he's told himself - his heart of darkness now re-made. Her horror coming up from the cracks - the surface lies. her journey now into the territory of the emotion, placed, just as she, in Alberta. Her horror - the absence of love told over and over - and under it, the pursuit of power.

over these 1001 nights on the beach

Scheherazade faces death:

now language

not sex

now language

not death

The body's speech calling her again - the heart of the matter spellbound. The disappearing father figure dispelled when she tells him, "In the second negative, he had almost left, was passing out of the frame. No longer bound to the family, but still loyal. Not dead, still living. But almost out of the picture - on the moon." She talks about him still in terms of story: "The Disappearing Father: Sorry and Absence." Absent, moving out of frame. Traces in her body. She is taking apart the world and putting it together again. And the story's circle is taking her through family: from sister to brother, mother and father. 
Scheherazade peoples her stories with others bargaining with their fates: their stories or their lives. Plotting to create Time and Life, she replays, reconstructs the memory of the two sisters: able to tell their stories so well they begin to tell the other's story, act as agents collecting danger, using insurance and credit to ward off fate and death and love.

We tell ourselves story, the fragments linked by time. Our bodies the place where the plot begins.

Scheherazade's Sister's Story: Another Heart in Darkness.

You lost yourself on that highway on that long drive back from Edmonton, lost in a way that was difficult for me to understand. Now there is no long river taking us farther into darkness. There is a road, and our faces in darkness with intermittant light beams throwing shadows. Light and dark. Light then dark. The steady stream: traffic coming toward us, driving us down to the city we are from, and are going back to, Calgary.

It was winter. The number 2 highway a landscape of line, even in darkness, lights on the horizon extending out across. Line and line of road, cars. This night, the oncoming light gave glimpses: your face and then shadow. Voice, what I hang onto.

My impulse to leave balanced by a stubbornness, to see this through to its end. What is the plot?

the two of us

eyes straight ahead

both passenger and driver fixed on a point

in the distance

blood

sisters

relations

doubles mirroring the other

doubled lives with our telling

doubled to outwit the inevitable

sisters, together, the fates:

you, the measurer

me, spinning, telling and her, the cutter

of life's thread bringing in death, she's absent

our histories shared now

kept to evade

another

inevitability

death: the disappearing father

sorry and absence

left and never came back 
a crashed plane

accident error

now love becomes horror

and then there is love and the absence of

love in the changing landscapes of Lacombe, Innisfail, Olds

and Airdrie. The emotions charting place

territory of the emotion

body in place

so now we take out insurance against death, against accident

cut out

replace

become immune to loss of any kind: theft, fire, Acts of God

now there is no accident, both of us investigators, private

eyes

independent agents

Theft, fire and Acts of God on my office door. Inside, a sweeping marble stairway out of Grand Hotel (the movie) like that lawyer's office (Burnett Duckworth) in Esso Plaza, the one that's all green marble, apricot Chinese rugs, silvered venetian blinds and the sweeping stairway. "Calming," one of the senior partners explains. "And a little different from the usual oak."

And our office, unlike theirs bare, left over from the boom, with only the sweeping staircase and the view extending out, high above the river valley, the other offices. Here, from Bow Valley Square, the twenty-second floor, I can look down at the rooftops, the missing letters on the Family Life Insurance Building. Our insurance, not on family life, but life itself.

Insurance a justice, a reckoning, a leveling out. A way of making sense of her life here in the late twentieth century Canada. Within a system that swallows up lives, measures made to fit details. Not just in the investigations she has to make. With her clients, the claimants who make lists of their missing objects. Her job to find if the items have really gone missing, located now in some other place than the imagination. Sometimes it's hard to believe the lists: the toasters and towels, the cold chicken and vodka, the anchovies and the blenders, the stereo and the iron, the mitts and the jewellery. So she'd watch. Their faces. Body.

Gesture. Are they acting natural? Acting. What is natural? Rehearsed. She practices now, in front of customs officials. Lies, says she bought more, invents items, a kind of reverse psychology with fate. More than innocent. Willing to lie to make the appearance. Having to act to look natural. No, she doesn't blame the claimants. It makes the work more interesting to look through the lawyers, covered up, to see in reversal. She knows she can't trust her five senses. 
"This, believe it or not," I told my boss, "came from that film course I took in the evenings: the study of Hitchcock, swept into horror with Jimmy Stewart in Vertigo, he, the detective with acrophobia, fear of heights, fear of falling who has to witness three deaths by falling: the first, an accident; the second, a murder, and the third, an inevitability. He's the dupe who becomes a killer: takes the murdered woman's double, remakes her into the other (a lover), then leads her over the edge (another woman falling) to her death. That's how I learned it: my distrust of appearances and the male order, and my suspicion of calm. Why I'm always waiting..." And now my method works so well that I'm training the other agents. Giving them my fear. I wonder.

And you too, live in a world of intrigue and mystery. Our family of agents. Collecting danger, death and adventure. Collecting to contain it. Inevitability in our files, along with our clients' histories. Your dream, as a collection agent from Mastercard is a client gone missing, Mexico maybe (it was a wintry Calgary September day) and although the customer later claimed innocence (it seemed she had already made her monthly payment and besides, the Credit Department had extended her credit further, taking her over the edge of fiscal responsibility. A pass across the border of spending limits, from a tight economy into the area of endless zeroes and no return. Fiscal heaven. In that territory of falling (a tortoise killing Aeschylus) and flying (Icarus moving up toward the sun). In that territory of sky above prairies (I saw it from Bow Valley Square, the twenty-second floor), money and magic merged. You, as a collection agent, represent the point where the banking system coincided with her life as a Mount Royal College instructor. You, in collections, hadn't been informed of the Credit Department's actions. The computer hadn't broken down. It just isn't that fast. So you told the instructor, with some delight, that you'd hired a skip tracer to find her. Hadn't skipped town to Mexico, though. A pity. A Mount Royal College account. Would have made a good file. And you, the repo woman in your dreams (the one who repossesses), were unable to carry it through. The customers keep paying the money back.

You with credit, me with insurance, we could do a lot. Could have helped Aeschylus, not with Mastercard but Visa, an exit Visa, helped him to meet his fate, his death which was to come from the heavens. Could have possibly postponed that eagle in flight, kept it from dropping the falling tortoise: it was the falling which killed him. Or bought Orestes some time, the furies who chased him down. Blood red eyes. Snakes in their hair. Revenge. Retaliation. Destruction. And the unnameable. Could have bargained with his fate.

And with mine. What I'm trying to escape. Now telling you every thing about (anything to fill in the hole between us), the drive losing me in the darkness and light. About being an agent, travelling, my life in hotels. A preference for isolation. The present without a past in Ottawa, Toronto, Vancouver, Montreal. Or a chance to recapture pasts I've never finished. 
Moving now through Olds, close to the end, I wonder if you are seeing someone else; startled, I look out my window, the direction of your gaze. See only darkness. Look and look again. Who do you see now? The Japanese princess, from Kurosawai's film, stamping her feet, disagreeing with everyone? Her father taught her to think like a man. And me? You think. We think together in silence.

\author{
after it's all over \\ the story is somewhere \\ buried \\ over and over \\ into the other \\ body \\ the drifting land, the moving \\ sea she and sand \\ the movement of story - time \\ and Scheherazade living on \\ borderlines
}

